\title{
Liability of Mining Companies on Environmental Impact Issued by Law No 32 Year 2009 on Protection and Management of Environment
}

\author{
Ruth Caroline R.A. Silalahi \\ Program Doktor Ilmu Hukum \\ Universitas Borobudur \\ Jakarta, Indonesia \\ ruthcras@gmail.com
}

\begin{abstract}
The abundant natural resources and energy are Indonesia precious wealth. The potential of metallic mineral resources and reserves is spread over 437 locations in westem and eastern Indonesia. But in fact, many people can find disadvantages from these activities, there are still many companies that can only use the environment for their self advantage and abandoned the healthy of the environment itself. This study aims to determine the accountability of the company from the mining company after its management with the governance regulation. This research is using normative legal research method by collecting data that comes from the literature study and that is the legislation literature study as the basic material of law and the other literature such as books, articles and written information from Internet. The results showed that the enormous responsibility for the environment to be lived by post-management mining companies is a form of responsibility that is very important for companies in the mining sector which aims to restore the environmental and ecosystem functions that had been disrupted due to mining activities. Based on law number 40 year 2007 Concerning Limited Liability Company Article 74 paragraph (1) states that the Company which carries out its business activities in the field and / or related to natural resources is obliged to carry out Social and Environmental Responsibility. This is further clarified by paragraph (3) Any Company that does not perform its obligations as referred to in paragraph (1) shall be liable to sanctions in accordance with the provisions of laws and regulations. So also regulated in Law Number 39 Year 2009 on Environmental Protection and Management.
\end{abstract}

Keywords - mining company, responsibility, environment

\section{INTRODUCTION}

\section{A. Background}

Natural resources that our country has is a great gift from God, it has become our right and responsibility to be able to use it wisely. It is also a big responsibility for the state and local government to cultivate nature for the sake of people welfare. At first, mining was done solely for the development of the State and people's welfare as stated in Article 33 paragraph (3) of the 1945 Constitution but in fact it is the opposite, mining companies mostly only reap their own personal profit without thinking about the environment that is still far from welfare, there are still many children who drop out of school, and there are still many people who live in poverty.

Law number 4 of 2009 on Mineral and Coal Mining Article 1 paragraph (26) stated "Reklamasi adalah kegiatan yang dilakukan sepanjang tahapan usaha pertambangan untuk menata, memulihkan dan memperbaiki kualitas lingkungan dan ekosistem agar dapat berfungsi kembali sesuai peruntukannya" Reclamation is a business restoration of post-mining environ ment either reforestation or replanting on post-mining land. Where mining companies are responsible for restoring the environment that had been damaged by mining activities that could later be reused. Law number 4 of 2009 Article 1 paragraph (27) mention reclamation and after mining. Article 2 paragraphs (1), (2), (3) and (4) concerning Pr "Kegiatan pascatambang yang selanjutnya disebut pascatambang, adalah kegiatan terencana, sistematis, yang berlanjut setelah akhir sebagian atau seluruh kegiatan usaha pertambangan untuk memulihkan fungsi lingkungan alam dan fungsi sosial menurut kondisi lokal diseluruh wilayah penambangan". Nowadays, the more world concern more about the environment. This is the most specific spotlight among the governance and the public. A clean and comfortable environment must be a vision for people welfare. With keeping our environment health, we can gain maximum benefits from a beautiful and comfortable environment.

In government regulation number 78/2010 concerning "Kegiatan pascatambang yang selanjutnya disebut pascatambang, adalah kegiatan terencana, sistematis, yang berlanjut setelah akhir sebagian atau seluruh kegiatan usaha pertambangan untuk memulihkan fungsi lingkungan alam dan fungsi sosial menurut kondisi lokal diseluruh wilayah penambangan". Nowadays, the more world concern more about the environment. This is the most specific spotlight among the governance and the public. A clean and comfortable environment must be a vision for people welfare. With keeping our environ ment health, we can gain maximum benefits from a beautiful and comfortable environment.

In government regulation number $78 / 2010$ concerning "Kegiatan pascatambang yang selanjutnya disebut pascatambang, adalah kegiatan terencana, sistematis, yang berlanjut setelah akhir sebagian atau seluruh kegiatan usaha pertambangan untuk memulihkan fungsi lingkungan alam 
dan fungsi sosial menurut kondisi lokal diseluruh wilayah penambangan". Nowadays, the more world concern more about the environment. This is the most specific spotlight among the governance and the public. A clean and comfortable environment must be a vision for people welfare. W ith keeping our environ ment health, we can gain maximum benefits from a beautiful and comfortable environment.

In government regulation Number 78 of 2010 on the Reclamation and Post Mining Principles which stated:

1. Holders of Izin Usaha Penambangan (IUP) and Izin Usaha Pertambangan Khusus (IUPK) is compulsory to bring license for exploration.

2. Holders of Izin Usaha Penambangan (IUP ) and Izin Usaha Pertambangan Khusus (IUPK) is compulsory to do reclamation and post mining.

3. Reclamation as referred in paragraph (1) shall be conducted on disturbed land in exploration activities.

4. Reclamation and post-mining as referred in paragraph (2) shall be conducted on disturbed land in mining activities by system and method: (a) open mining; and (b) underground mining

If mining activities not properly implemented it can have a negative impact on the environment. Environmental impacts of mining activities include: decreased land productivity, increased filthy soil, erosion and sedimentation, soil movement or landslides, disruption of flora and fauna, disruption of public health, and micro-climate change. Reclamation activities should be done as early as possible and should not wait for the mining process as a whole to be completed. Proper planning and implementation is a continuous and environmentally sound management of mining that will reduce the negative impact of mining business activities.

\section{B. Research Questions}

Based on what has been described on the background above, the subject matter in this study as follows:

1. How is the Mine Company'S liability program for post mining activities based on Law number 32 of 2009 on Environmental Protection and Management also Government Regulation No. 78 Year 2010 on Reclamation and Post Mining?

2. How to grant sanctions to Mining Companies that neglect their post-mining responsibilities under Law number 32 of 2009 on Environ mental Protection and Management and Government Regulation number. 78 of 2010 on Reclamation and Post Mining?

\section{Research Methodology}

This paper includes normative research which is also often referred to doctrinal research with the object or target of research in the form of regulations, legislation and other legal materials. The result of legal research is not to find a new legal theory at least is a new argument. In research conducted is the normative juridical that is by examining the subject matter as mentioned above. In addition, the research will also complement from other relevant aspects based on the scope and identification of the problem formulated.

Research on the Mining Corporation's Responsibility to Environ mental Impact will be conducted by library research and empirical research. In the empirical research will be generated primary data, and from library research will be obtained secondary data to be obtained illustration of how the practice of legislation governing foreign workers applied in the field.

\section{DISCUSSION}

A. Accountability of Post-mining for Mining Companies based on Law number 32 Year 2009 on Environmental Protection and Management and Government Regulation number 78 Year 2010 on Reclamation and Post Mining.

Social and Environment Responsibility is a compulsory part that must be implemented by the company itself. As stated in Law number .40 of 2007 on Limited Liability Companies where the government strictly stipulates that companies that conduct their business activities in the field and / or related to natural resources are obliged to carry out Social and Environmental Responsibility. In this case the author will give an example case of PT. Newmont Minahasa Raya (Sulawesi). PT. Newmont Minahas a Raya is one of the famous gold mining companies in North Sulawesi that successfully runs the responsibilities of post-mining companies especially to the environment. Although in its development we could know together there is an unpleasant news on PTNMR that is about the cause of pollution of Buyat Bay (Manado District Court Decision Number 284 / Pid.B / 2005).

PT Newmont Minahasa Raya has operated a gold mine in Southeast Minahasa District, North Sulawesi Indonesia from 1996 to 2004 followed by a period of monitoring until 2009. The Responsible Mine Closure Program through reclamation has successfully restored the ecological function of the reclamation area of 240.41 hectares. The former mine area has become a reclaimed forest where it has found high value economic plants growing and a variety of rare animals can be found in its natural habitat. The following are the types of PTNMR's corporate liability programs in accordance with their original environmental and social data including :

\section{a) Arrangement of Water and Land}

The process of reclamation is done gradually with the arrangement of land, erosion prevention, spreading of soil shoots, planting cover and planting trees. Planting followed followed by maintenance ie watering, weeding, crop replacement and growth monitoring. Wetland (wetland) is created to maintain water flow and sedimentation, to breed birds and aquatic plants, creating an ecosystem that will support the ecological function of reclaimed forests. Water in the reclaimed forest will be a natural reservoir for the forest and its contents als o for the surrounding community

\section{b) Commitment to Post-Mining Sustainable Development}

The potential impact of mine closure on social and economic aspects of local communities has been identified through a consultation process. PTNMR is committed to promoting sustainable development and, if possible, to meet 
the economic, social and environmental needs for sustainable development to become a reality.

\section{c) Development of Lakban and Buyat Bay tourist areas}

PTNMR has built tourist area in Lakban and Buyat Bay area with various sports game facilities and coast guard building. A mazing underwater tours are located in Buyat Bay and its surroundings with 24 dive spots that have become one of the dive destination in North Sulawesi. Certainly can bring income for the region and economic potential for the local community.

\section{d) Development of Community Based Foundation}

PTNMR established three community-based foundations to continue the sustainable development that has been initiated since the early days of the mine. PTNMR also established the Ratatotok Buyat Sustainable Development Foundation (YPBRB) with local communities (in 2008). YPBRB has set up Taman Bacaan, Community Radio, Smart House and distributed micro credit grants and scholarship assistance in health and education.

\section{e) Mangrove Forest Rehabilitation}

Mangrove protection and conservation activities in coastal areas of Ratatotok and Buyat. Community mangrove planting work groups have been established. Up to now, 50,000 mangrove trees have been planted in 5 hectares of village land.

\section{f) Flora and fauna}

Periodic surveys in six years also found 109 species of sedentary birds and migration in mine reclaimed forest areas such as Rangkong, Kadalan Sulawesi and Yellow-sided flowerpecker. Also found are the ever-increasing species of pollinating insects and endangered animals such as Sulawesi dwarf monkeys (Tarsius sp)

First, confirm that you have the correct template for your paper size. This template has been tailored for output on the A4 paper size. If you are using US letter-sized paper, please close this file and download the Microsoft Word, Letter file.

\section{B. Sanctions for Mining Companies Ignoring Postpartum \\ Responsibility under Law Number. 32 of 2009 on \\ Environmental Protection and Management and \\ Government Regulation Number. 78 of 2010 on \\ Reclamation and Post Mining}

In Law Number. 40 Year 2007 Concerning Limited Liability Company Article 74 paragraph (1) states that Perseroaan conducting its business activities in the field and / or related to natural resources shall be obligated to carry out Social and Environmental Responsibility. Similar to Government Regulation no. (1): IUP, IUPK or IPR holders violating the provisions referred to in Article 2 paragraph (1) or paragraph (2), Article 3 paragraph (1) or Paragraph (2), Article 4 paragraph (4), Article 5 paragraph (I), Article 14 paragraph (I), Article 17 paragraph (I), Article 20 paragraph (I), Article 21, Article 22 paragraph (I) Article 25 paragraph (I), paragraph (2), or paragraph (3), Article 26 paragraph (I), Article 29 paragraph (I), Article 41, Article 45 paragraph (2), Article 47 paragraph (I) Article 48 is subject to administrative sanctions. Article 50 (2): The administrative sanctions as referred to in paragraph (1) may be: a. written warning; $b$. temporary suspension of activities; and / or c. revocation of
IUP, IUPK, or IPR. Article 50 paragraph (3): IUP, IUPK or IPR holders subject to administrative sanctions in the form of revocation of IUP, IUPK or IPR as referred to in paragraph (2) letter $\mathrm{c}$ shall not eliminate its obligation to undertake reclamation and post-mining activities. Article 50 paragraph (4): The administrative sanctions as referred to in paragraph (1) shall be granted by the Minister, governor or regent / mayor in accordance with their authority.

Many legal experts believe that the sanctions in the form of administrative sanctions in the PP are still weak, in fact there are still many mining companies and officials authorized to grant permits that disregard the rules and still commit violations, and only subject to administrative sanctions only.

This should be considered for the regulatory authorities, such as enforcing criminal sanctions. It relates to a company that runs its business or activity on natural resources, meaning to enter in an environ mental tone. As we know with the company of course can be subject to criminal sanctions referring to Law no. 32 of 2009 on the Protection and Management of the Environment. In Law nu mber 32 of 2009 on Environ mental Protection and Management of the fourth section on the Restoration of Article 54 paragraph (1) which stated:

"Setiap orang yang melakukan pencemaran dan/atau perusakan lingkungan hidup wajib melakukan pemulihan fungsi lingkungan hidup”.

Article 54 paragraph (2): "Pemulihan fungsi lingkungan hidup sebagaimana dimaksud pada ayat (1) dilakukan dengan tahapan :

a) Penghentian sumber pencemaran dan pembersihan unsurpencemar;

b) Remediasi;

c) Rehabilitasi;

d) Restorasi;

e) Cara lain yang sesuai dengan perkembangan ilmu pengetahuandan teknologi,"

Article 54 paragraph (3) : further provisions concerning the procedure for the restoration of environmental functions as referred to in paragraph (2) shall be stipulated in a Government Regulation.

In this case reclamation and post-mining are a huge responsibility for mining companies which are activities aimed at restoring environmental functions in accordance with their designation so it is clear that it is related to the recovery of environment damaged by mining activities. And if it is not done then the company that runs the business or activity must be subject to criminal sanctions aimed at providing a deterrent effect.

The weak regulations are made in the Government Regulation number 78 on Reclamation and Post-Mining and Law number 4 of 2009 on Mineral and Coal Mining does not include criminal sanctions on non-implementation of postmining reclamation responsibilities by mining companies or holders of IUP, IUPK and IPR in it. Not out of the above understanding, but criminal sanctions can be given to mining companies that cause damage to the environment. In Law no. 32 of 2009 in Chapter 15 on the criminal provisions of Article 98 paragraph (1), paragraph (2), and paragraph (3), stated : 
1) Setiap orang yang dengan sengaja melakukan perbuatan yang mengakibatkan dilampauinya baku mutu udara ambien, baku mutu air, baku mutu air laut atau kriteria baku kerusakan lingkungan hidup, di pidana dengan pidana penjara paling singkat 3 (tiga) tahun dan paling lama 10 ( sepuluh) tahun dan denda paling sedikit Rp.3000.000.000,00 (tiga miliar rupiah) dan paling banyak Rp. 10.000.000.000,00 (sepuluh miliar rupiah)."

2) Apabila perbuatan sebagaimana dimaksud pada ayat (1) mengakibatkan orang luka dan/atau bahaya kesehatan manusia, dipidana dengan pidana penjara paling singkat 4 (empat) tahun dan paling lama 12 (dua belas) tahun dan denda paling sedikit Rp. 4.000.000.000,00 (empat miliar rupiah) dan paling banyak Rp. 12.000.000.000,00 (dua belas miliar rupiah)

3) Apabila perbuatan sebagaimana dimaksud pada ayat (1) mengakibatkan orang luka berat atau mati, dipidana dengan pidana penjara paling singkat 5 (lima) tahun dan paling lama 15 (lima belas) tahun dan denda paling sedikit Rp. 5.000.000.000,00 (lima miliar rupiah) dan paling banyak $R p$. 15.000.000.000,00 (lima belas miliar rupiah).

In Law number 32 of 2009 on Article 88: any person whose actions, business and / or activities use B3, produce and / or manage B3 waste, and / or poses a serious threat to the environment responsible for the absolute loss that would occur without the need proof of error element. So it involves a corporation which, when running its activities or business, is directly related to the environment. Because there is an absolute responsibility that is incorporated into legislation. Corporate social responsibility is fundamentally a matter of course when it comes from a basic understanding that a company is a part of society. As a part, the company must have a positive and negative impact. Is sues that make it difficult and even complicated, because not all parties, both every company and every stakeholder consciously always responsible for any consequences that have been done.

\section{CONCLUSION}

\section{A. Conclusion}

The current weak regulations are made because there is no firm sanctions in the company carry out its responsibilities. So in addition it is still mining companies responsibility, but in fact there are many other mining companies that do not carry out responsibilities as they should. This is what should be much noticed by the government because if many of the holders of IUP, IUPK and IPR are not responsible both the environment and surrounding communities then the government will be affected.

\section{B. Suggestions}

Due to the weakness of the current Laws and Government Regulations, have resulted where many mining companies not performing their responsibilities as they should. So the government should make more strict sanctions and if necessary to provide sanctions layered to companies that neglect in carrying out corporate responsibility and give the highest award for companies that carry corporate responsibility of course as a form of appreciation and thanks to companies who want to help even working with the government.

For mining companies that will hold mining activities in a region or region is expected to hold socialization activities with the surrounding community in order to understand and establish good cooperative relationships.Abbreviations and Acronyms

\section{REFERENCES}

[1] Sukandarrumidi. (2010). Memahami Pengelolaan Bahan Tambang Di Indonesia Referensi Undang - Undang Minerba No. 4 Tahun 2009. Yogyakarta: Yayasan Pustaka Nusantara.

[2] Supramono, G. (2012). Hukum Pertambangan Mineral dan Batubara Di Indonesia. Jakarta: PT Rineka Cipta.

[3] Hadi, N. (2011). Corporate Social Responsibility. Yogyakarta: Graha ilmu.

[4] Keraf, A. (2010). Etika Lingkungan Hidup. Jakarta: PT Kompas Media Nusantara.

[5] Salim, H. (2012). Hukum Pertambangan Mineral dan Batubara. Jakarta: Sinar Grafika.

[6] Muladi dan D Priyatno. (2010). Pertanggungjawaban Pidana Korporasi. Jakarta: Kencana Prenada Media Group.

[7] Erwin, M. (2008). Hukum Lingkungan Dalam Sistem Kebijaksanaan Pembangunan Lingkungan Hidup. Bandung: PT Refika Aditama.

[8] UU R.I No. 4 Tahun 2009 tentang Pertambangan Mineral dan Batubara. Yogyakarta: Yayasan Pustaka Nusantara.

[9] UU R.I No. 40 Tahun 2007 tentang Perseroan Terbatas. Jakarta: Indonesia Legal Center Publishing.

[10] UU R.I No. 32 Tahun 2009 tentang Perlindungan dan Pengelolaan Lingkungan Hidup dan Amdal. Yogyakarta: Pena Pustaka.

[11] Kitab Undang-Undang Hukum Perdata, Jakarta, Wipress. 